Катерина Ковальська,

кандидат історичних наук, дочент кафедри географії, екології та методики навчання ДВНЗ «Переяслав-Хмельницький державний педагогічний університет імені Григорія Сковороди».
Katerina Kovalska,

Ph.D. in History, Associate Professor of the Department of Geography, Ecology and Methods of Teaching SHEI «PereyaslavKhmelnytskyi Hryhoriy Skovoroda State Pedagogical University».

\title{
УМОВИ ЕФЕКТИВНОГО ВИКОРИСТАННЯ МУЛЬТИМЕДІЙНИХ НАОЧНИХ ПОСІБНИКІВ У ПРОЦЕСІ НАВЧАННЯ ГЕОГРАФІЇ В ШКОЛІ
}

У статті розкрито головні умови, щуодо застосування мультимедійних посібників, подано етапи підготовки та створення мультимедійних посібників, а також висвітлено переваги використання мультимедійних посібників у прочесі навчання географії, на основі власних досліджень.

Доведено, що ефективнішим у викладанні природничих дисциплін, зокрема географії є мультимедіапідхід, заснований на використанні декількох взаємодоповнюючих інформачійних технологій. Сьогодні ні у кого не викликає сумніву той факт, щэо електронні навчальні посібники дозволяють збагатити шкільний освітній курс, доповнюючи його можливостями комп'ютерних технологій, і роблять його, таким чином, цікавішим і привабливішим для учнів. Виключно висока міра наочності представленого матеріалу, взаємозв'язок різних компонентів курсів, комплексність та інтерактивність роблять електронні навчальні посібники з географії незамінними помічниками, як для учня, так і для вчителя. Розробка мультимедійних посібників з використанням інноваційних технологій є перспективним напрямком.

Ключові слова: мультимедійні технології, мультимедійні засоби навчання, навчальний процес, мультимедійні презентації, електронний навчальний атлас, мультимедійні посібники, географія, пізнавальна діяльність учнів, інформачійно-комунікачійні технології, географічна освіта.

The main conditions for the using of multimedia manuals are opened in the article, the stages of preparation and creation of multimedia manuals are gave, and also the advantages of using multimedia manuals in the process of teaching of geography, on the basis of their own researches are elucidated in it .

The more effective in teaching natural sciences, in particular geography, is a multimedia-approach based on the use of several complementary information technologies, is proved. Today, is the fact that electronic manuals can enrich of the school educational course, complementing it with the capabilities of computer technologies, and make it, thus, more interesting and attractive for pupils. The extremely high measure of clarity of the presented material, the relationship different components of the courses, complexity and interactivity make of electronic manuals from geography indispensable aides, as for the pupil and teacher. The development of multimedia manuals with using innovative technologies is a perspective direction.

The ability to work with information increases the competitiveness of the pupil the first in the educational environment, and later in the field of his professional activity, formed of the ability to self-improvement, independent search, creativity, changing of the relationship «teacher-pupil», there is an atmosphere of cooperation, partnership is revealed in the article. Contributes to the formation of personality, capable not only to search and creativity, but also fruitful communication and manifestations of tolerance in relations with people.

The using of multimedia teachingmanuals in geography lessons is a means of increasing the motivation of pupilss to study the subject and improving of the quality of knowledge. This leads to the activation of cognitive activity of pupils, the development of their creative thinking, the formation of active position of the individual in modern information society. The using of considering means ensures the development of creative abilities of schoolchildren and the desire to continue of independent and cognitive work. The using of information and communication technologies in the teaching of geography in secondary school allows to achieve a new quality of knowledge.

The using of multimedia manuals makes possible of all human senses for achieve new things, forms a colourful, big image of the object it studying, creates of associative links, contributing of the best assimilation of the material in question. Multimedia, teaching manuals activate of previously acquired knowledge, develop of logical thinking, allow to strengthen of the creative component of educational work. Increase of qualification of geography teachers in the field of information and communication technologies is a necessary condition for reformation of school geographical education. 
Keywords: multimedia technologies, multimedia means of education, educational process, multimedia presentations, electronic educational atlas, multimedia manuals, geography, cognitive activity of students, information and communication technologies, geographical education.

Постановка проблеми. В умовах переходу до інформаційного суспільства зміни відбуваються в усіх сферах нашого життя. Відбувається впровадження комп'ютерної техніки в процес навчання географії. На сучасному етапі діє державна програма комп'ютеризації шкіл, здійснюється забезпечення комп'ютерної техніки й підключення шкіл до мережі Інтернет. Перед шкільною географією стоїть завдання вдосконалення програм, розробки стандартів географічної освіти, нових концепцій навчання й виховання людини XXI ст. 3 інтенсивним та ефективним використанням географічних знань.

Комп'ютер у навчальному процесі є не лише джерелом інформації, а й засобом навчання й тим інструментом, що дозволяє активізувати процес пізнавальної діяльності, сприяє розвитку гнучкості мислення, формує вміння учнів орієнтуватися й адаптуватися в сучасному світі. Виховання цих якостей учителем практично є неможливим без використання інформаційних технологій у викладанні географії.

Уміння працювати 3 інформацією підвищує конкурентоспроможність учня спочатку в освітньому середовищі, а згодом і в галузі його професійної діяльності, формується здатність до самовдосконалення, самостійного пошуку, творчості, змінюються стосунки «учитель - учень», виникає атмосфера співпраці, партнерства. Сприяє формуванню особистості, здатної не лише до пошуку й творчості, але й плідного спілкування і проявів толерантності в стосунках з людьми [Заєuь, 2014: $c$. 6-9].

Основна мета сучасної географічної освіти полягає у всебічному розвитку особистості учня з урахуванням його природних задатків, здібностей, інтересів та потреб через формування географічної культури, як основи світосприйняття, світогляду та діяльності. Сьогодні завдання вчителя полягає в тому, аби відібрати зі своїх методичних надбань усе прогресивне i змінити, модернізувати, трансформувати навчальний процес так, щоб забезпечити дослідницький, пошуковий характер, що сприятиме розвитку мислення та розумових творчих здібностей учнів [Пехота, 2004: c. 44-46].

Аналіз останніх досліджень $\boldsymbol{i}$ публікацій. На сьогодні проблемам впровадження й ефективного застосування педагогічних технологій присвячено чимало наукових досліджень вітчизняних та зарубіжних дослідників ними є: С. Бондарь, Б. Блум, Д. Брунер, I. Дичківська, Дж. Кэррол, К. Мередит, Л. Пироженко, О. Пометун. Такі вчені, як Н. Лєскова, С. Кобернік, С. Пальчевський, Г. Пустовіт, А. Сиртенко, Б. Чернов в останніх публікаціях розглядали певні аспекти інноваційних підходів у викладанні географії. Технологія проблемного навчання заснована була на теоретичних положеннях американського філософа, психолога $\mathrm{i}$ педагога Дж. Дьюї.

Інформаційно-комунікаційні технології дозволяють більш ефективно використовувати час при роботі з доповідями, рефератами, науковими роботами. Неможливо уявити самостійну дослідницько-пошукову діяльність учня без Інтернету. Самостійна робота 3 Інтернетом допомагає учню долати лінощі думки, 
виробляє здатність критично мислити, а не користуватись чужими думками, готовими результатами [Кушнаренко, 2014: с. 52].

Досвідчені педагоги використовують мультимедіа для розробки навчальних технологій та створення сучасних ефективних засобів навчання та вдосконалення ефективності навчального процесу. Науковці довели, що заняття із застосуванням мультимедія - барвисті, наочні, динамічні та краще запам'ятовуються, але зазначають, що розумно мультимедійний супровід занять і традиційні методи викладання [Пометун, 2004: с. 192].

На сьогодні вже набуто певний досвід застосування мультимедійних технологій під час вивчення географії, який свідчить про невпинний інтерес вчителів до пошуку шляхів ефективного використання вищезазначених технологій як засобу розвитку пізнавальної активності учнів.

Mema cmammi - 3'ясувати умови ефективного використання різноманітних мультимедійних посібників та розкрити особливості їх використання у процесі навчання географії в школі.

Завдання полягає у дослідженні теоретичних підходів і практики використання елементів мультимедійних засобів у навчальному процесі. Аналізу проблеми використання мультимедійних посібників на уроках географії. 3`ясувати практичний стан використання мультимедійних методів навчання на уроках географії. Розглянути можливості мультимедійних посібників, як засобу підвищення пізнавальної активності учнів.

Виклад основного матеріалу. У навчальний процес шкіл України все частіше впроваджуються мультимедійні засоби навчання. В широкому сенсі «мультимедіа» означає спектр інформаційних технологій, що використовують різноманітні програмні та технічні засоби з метою найбільш ефективного впливу на користувача (що став одночасно і читачем, i слухачем, i глядачем). Завдяки застосуванню в мультимедійних продуктах і послугах одночасної дії графічної, аудіо (звукової) і візуальної інформації ці засоби володіють великим емоційним зарядом і активно включають увагу користувача (слухача). Дані засоби навчання дають змогу створити нове навчальне середовище, яке здатне підвищити якість географічної освіти, залучитися до світового інформаційного простору. I у цьому середовищі наголос робиться не на вивчення фактологічного матеріалу, а більше на розвиток навичок мислення, міжособистісних відносин і творчості.

Географія дає багатий матеріал для відпрацювання найрізноманітніших методів і прийомів роботи з інформацією. При цьому можна вибрати для постійного застосування найоптимальніші 3 них. Крім того, географія має також інші специфічні особливості, які дають можливість застосовувати мультимедійні засоби 3 найбільшою ефективністю. До них належить відповідність певного масиву інформації до визначеної території. Викладання географії пов'язане з використанням величезного обсягу найрізноманітнішої інформації, що робить застосування мультимедійних технологій особливо ефективним. 3 іiі допомогою створюється база даних про всі материки й частини світу, найбільші країни, регіони, міста тощо.

Загалом, виходячи із загальних засад методики викладання географії, мультимедійні засоби використовуються $з$ метою:

а) демонстрування й розкриття особливостей i закономірностей розвитку географічних явищ; б) показу певної території, іï комплексної характеристики й виділення характерних особливостей; в) демонстрування різних схем, карт, графіків, таблиць, фотографій, тощо; г) контролю знань, умінь і навичок учнів; 
б) проведення географічних ігор.

Використання мультимедійних засобів на уроках географії відбувається завдяки таким методам, як:

- системний аналіз;

- методи передачі, збереження та захисту інформації;

-безпаперові технології;

- методи колективного використання різноманітних інформаційних ресурсів.

Вищезазначені методи дають можливість учителю географії досягти дидактичної мети, застосувати як окремі методи навчальної роботи, так i спроектувати навчальне середовище [Пирогов, 2011: с. 7-8].

Застосування всіх видів мультимедійних засобів навчання спрямоване на підвищення позитивної мотивації учнів до вивчення шкільних предметів, зокрема географії. Це веде до активізації пізнавальної діяльності учнів, розвитку їх творчого мислення, формування активної позиції особистості в сучасному інформатизованому суспільстві. Використання зазначених засобів забезпечує розвиток творчих здібностей школярів і бажання продовжити самостійну і пізнавальну роботу.

Важливе місце на уроках посідають мультимедійні презентацій. Презентація - це набір послідовно змінюючих одна одну сторінок - слайдів, на кожній з яких можна розмістити будь-який текст, малюнки, схеми, відео - аудіо фрагменти, анімацію, 3D - графіку, використовуючи при цьому різні елементи оформлення. Ця мультимедійна форма дозволяє подати матеріал як систему яскравих опорних образів, наповнених вичерпною структурованою інформацією в алгоритмічному порядку. Мета такого подання навчальної інформації, перш за все, у формуванні у школярів системи образного мислення [Бученко, 2007: c. 54]. Кожен учитель знає, як відбувається запам'ятовування інформації: якщо інформація сприймається тільки слухом, засвоюється 20\% іï обсягу; якщо лише за допомогою зору, запам'ятовується $30 \%$ матеріалу. За умови комбінованого поєднання «включення» слухового й зорового каналів інформації учень спроможний засвоїти до $60 \%$ інформації. А застосування мультимедіа дає змогу об'єднати текст, звук, графічне зображення, відео, зображення та ще й улюблену дітьми анімацію (мультиплікацію). Таким чином, використання мультимедіа значно сприяє засвоєнню навчальної інформації кожним школярем.

Систематичне використання мультимедійних презентацій на уроці сприяє:

- підвищенню якісного рівня використання наочності на уроці;

- зростанню продуктивності уроку;

- реалізації міжпредметних зв'язків;

- структуруванню навчального матеріалу, що значно підвищує рівень знань учнів;

-зміні ставлення школярів до комп’ютера, вони починають сприймати його не як сучасну іграшку, а як універсальний інструмент для ефективної роботи в будьякій галузі людської діяльності.

Використання презентацій є доцільним на будь-якому етапі вивчення теми i на будь-якому етапі уроку: під час пояснення нового матеріалу, закріплення, повторення, контролю. Щоб підготувати презентацію слід дотримуватись певних правил, крім того вона розробляється поетапно.

Етапи підготовки мультимедійної навчальної презентації :

1. Структуризація навчального матеріалу.

2. Складання сценарію реалізації. 
3. Розробка дизайну презентації.

4. Підготовка медіафрагментів (тексти, ілюстрації, відео, запис аудіофрагментів).

5. Підготовка музичного супроводу.

6. Тест-перевірка готової презентації.

Кожен навчальний мультимедійний засіб має відповідати всім дидактичним вимогам, що й традиційні посібники, а саме науковості, систематичності, послідовності, доступності, зв'язку із практикою, наочності. Проте під час створення мультимедійної презентації необхідно враховувати не тільки відповідні принципи класичної дидактики, але й специфічні підходи використання комп'ютерних мультимедійних презентацій. Важливим моментом є розподіл навчального матеріалу на слайдах: він повинен подаватися порціями, зручними для сприйняття. Нелогічно на одному слайді розміщувати багато інформації, навіть якщо вона має відношення до суті питання, що викладається на ньому [Бученко, 2007: с. 54].

Отже, за умови якщо презентація розроблена з дотриманням усіх правил то мультимедійна інформація, яка міститься в ній відрізняється чіткістю, лаконічністю, доступністю. У процесі роботи з нею учні вчаться аналізувати, висловлювати власну думку. Якщо застосування мультимедійних технологій добре продумане, заняття буде образним, наочним, цікавим, життєвим.

Презентація дає можливість вчителю проявити творчість, індивідуальність. Вона дозволяє представити навчальний матеріал як систему яскравих опорних образів, наповнених вичерпною структурованою інформацією в алгоритмічній послідовності. Під час використання презентацій задіяні різні канали сприйняття учнів, що дозволяє закласти інформацію не тільки у фактографічному, а й в асоціативному вигляді в пам'ять учнів.

Крім зазначених переваг, використання презентацій на уроці географії дає можливість:

- використати повноекранне відео, яке несе великий обсяг інформації, та й всі ми знаємо, що краще один раз побачити, ніж сто раз почути;

- використати значну кількість таблиць, малюнків, діаграм, портретів вчених, фотографій, карт, схем;

- активізувати сприйняття учнів за рахунок звукових та зорових демонстрацій;

- виділити головний зміст;

- під час пояснення не витрачається час на запис на дошці;

- під час пояснення вчитель не повертається до дошки, таким чином не втрачається контакт 3 класом;

- учням легше відповідати, коли вони спираються на відображений на екрані план відповіді.

Отже, мультимедійна презентація може містити текстові матеріали, фотографії, малюнки, слайд-шоу, звукове оформлення й дикторський супровід, відеофрагменти й анімацію, тривимірну графіку. Перевага комп'ютерної презентації полягає в полегшенні праці викладача й упорядковуванні та збереженні наочного матеріалу, необхідного для конкретного заняття. Комп'ютерна презентація не зможе замінити роботу викладача з класною дошкою, але значно спростить роботу під час демонстрації наочного матеріалу.

Ще одна безперечна перевага презентації перед розповіддю полягає в тому, що за необхідності можна повернутися до інформації, яку не зрозуміли учні. 
Наприклад, з дошки запис або схему вже стерто, а деякі учні не встигли їх опрацювати. У цьому разі викладачеві доведеться перервати розповідь і повернутися до попереднього матеріалу, що, природно, порушить хід викладу матеріалу й відверне інших учнів від роботи. А 3 допомогою комп'ютера лише за одним натиском можна повернутися до будь-якого незрозумілого моменту [Заєuь, 2014: c. 9].

Крім того існує велика кількість і інших електронних наочностей які можуть використовуватись на різних етапах уроку географіі. В цьому випадку ми розглядаємо принцип наочності як стимул в організації активної пізнавальної діяльності учнів та опиратися на представлені в засобах наочності образи, моделі, знаки. Комплекс інтерактивних й аудіовізуальних засобів виступає як стимулятор, що спонукує до пізнання, розвитку інтересу, уяви, що створює емоційну сферу навчання. До прикладу популярності набуває використання на уроках географії електронних навчальних атласів.

Електронний навчальний атлас 3 географії - це інтерактивний картографічний твір, зміст якого відповідає навчальним програмам, а засоби зображення та оформлення - віковим психологічним особливостям учнів, які інтегрують картографічне зображення 3 різноманітним текстом, фото- й відеоматеріалом, мають також підвищені аналітичні можливості. I головна перевага цих сучасних засобів у тому, що вони дозволяють підняти рівень викладання предмета за рахунок вирішення комплексу питань збільшення інформативності карт 3 одночасним забезпеченням простоти й легкості сприймання картографічного матеріалу. Електронний атлас забезпечує педагогічні та методичні можливості картографічного видання, робить його цікавим для сильного та зрозумілим для слабкого учня [Колмичков, 2006: c. 7-11].

Прикладом електронних наочностей є Бібліотека електронних наочностей 3 географії (7-11 класи), яка також набуває все більшої популярності, містить наочні матеріали і медіа об'єкти декількох категорій:

-фотографії конкретних географічних об'єктів 3 текстовими коментарями (наприклад, фото вулкана, природних комплексів Землі та ін.);

-схеми, діаграми, таблиці, що відображають будову географічних об'єктів, сутність географічних явищ $\mathrm{i}$ процесів, їх якісні й кількісні характеристики (наприклад, схема розповсюдження теплових, кліматичних поясів та повітряних мас);

-анімації та відеоролики, що відображають географічні процеси або явища 3 текстовими або звуковими коментарями (наприклад, глобальні проблеми людства, сучасні географічні дослідження та ін.);

-інтерактивні картосхеми, конструктори контурних карт, моделі форм рельєфу з текстовими та звуковими коментарями.

Застосовувати мультимедійну техніку, можна у будь-якій послідовності, перейти від одних об'єктів до інших, виділити головні фрагменти, скомпонувати кілька сюжетів, що дає змогу порівнювати, робити логічні висновки, узагальнювати та синтезувати, прогнозувати кінцевий результат.

Висновки. Використання мультимедійних посібників навчання на уроках географії є засобом посилення мотивації учнів до вивчення предмету та підвищення якості знань. Це веде до активізації пізнавальної діяльності учнів, розвитку їх творчого мислення, формування активної позиції особистості в сучасному інформатизованому суспільстві. Використання розглянутих засобів забезпечує 
розвиток творчих здібностей школярів i бажання продовжити самостійну i пізнавальну роботу. Застосування інформаційних і комунікаційних технологій при викладанні географії в середній школі дозволяє досягти нової якості знань. Використання мультимедійних технологій дозволяє задіювати всі органи чуття людини для досягнення нового, формує барвистий, об'ємний образ об'єкта, що вивчається, створює асоціативні зв'язки, сприяючи кращому засвоєнню розгляданого матеріалу. Мультимедійні, навчальні посібники активізують одержані раніше знання, розвивають логічне мислення, дозволяють підсилити творчу складову навчальної праці. Підвищення кваліфікації вчителя географії в галузі інформаційно-комунікаційних технологій - необхідна умова реформування шкільної географічної освіти [Кирилюк, 2011: с. 124].

Перспективи подальших досліджень полягають в обгрунтуванні раціональної побудови методичної системи навчання 3 використанням мультимедіа, a ii вирішення дозволяє забезпечити навчання учнів географії універсальними засобами для формування ключових компетенцій.

\section{ЛІТЕРАТУРА}

Бученко, 2007 - Бученко І. В. Комп’ютеризація навчання - свідчення професійної майстерності педагога. Інститут післядипломної педагогічної освіти / І. В. Бученко - К., 2007. - С. 54. Режим доступу: http://ippo.org.ua .

Гороль, 2007 - Гороль П. К. Сучасні інформаційні засоби навчання / П. К. Гороль, Р. С. Гуревич, Л. Л. Коношевский, О. В. Шестопалюк. - К.: Освіта України. - 2007. - 536 с.

Заєць, 2014 - Заєць Н. М. Сучасна наочність: переваги й можливості мультимедійної презентації / Педагогічна майстерня. - 2014. - № 12. С. 6-9.

Кирилюк, 2011 - Кирилюк С. М. Проблеми викладання географії у школі: Конспект лекцій / укл. Кирилюк С. М. - Чернівці: Чернівецький національнийуніверситет, 2011. - 124 с. Джерело: https://collectedpapers.com.ua/category/problems_teaching_geography_schoos

Колмичков, 2006 - Колмичков М. Використання електронних атласів на уроках географії / М. Колмичков // Краєзнавство. Географія. Туризм. - 2006. - №10-11. - С. 3-7.

Кушнаренко, 2014 - Кушнаренко Наталія. Застосування іноваційних технологій у навчанні фізичної географії. / Наталія Кушнаренко // Психолого-педагогічні проблеми сільської школи. Випуск 51. - 2014. - С. 52 58.

Маркус, 2002 - Маркус Н. В. Особливості застосування інформаційних технологій як засобу гуманізації навчання школярів / Н. В. Маркус // Оновлення змісту, форм та методів навчання і виховання в закладах освіти: 3б. наук. пр. - Рівне. - 2002. - С. 171-173.

Назаренко, 2008 - Назаренко Т. Г. Зміст і структура методики навчання географії в профільній школі / Т. Г. Назаренко // Географія та основи економіки в школі. - 2008. - № 7-8. - С. 18-20.

Новиков, 2003 - Новиков С. П. Применение новых информационных технологий в образовательном процессе / С. П. Новиков // Педагогика. - 2003. - № 9. - С. 32-38.

Пехота, 2004 - Пехота О. М. Освітні технології / за ред. О. М. Пєхоти. - К., 2004. - С. 44-46.

Пирогов, 2011 - Пирогов І. Мультимедійні засоби у навчанні географії / І. Пирогов // Краєзнавство. Географія. Туризм. - 2011. - № 38. - С. 7-8.

Пометун, 2004 - Пометун О. І. Сучасний урок. Інтерактивні технології навчання: науково-методичний посібник / О. І. Пометун, Л. В. Пироженко. - К.: Видавництво А.С.К., 2004. - 192 с.

\section{REFERENCES}

Buchenko, 2007 - Buchenko I. V. Kompiuteryzatsiia navchannia - svidchennia profesiinoi maisternosti pedahoha. Instytut pisliadyplomnoi pedahohichnoi osvity / I. V. Buchenko - K., 2007. - S. 54. Rezhym dostupu: http://ippo.org.ua .

Horol, 2007 - Horol P. K. Suchasni informatsiini zasoby navchannia / P. K. Horol, R. S. Hurevych, L. L. Konoshevskyi, O. V. Shestopaliuk. - K.: Osvita Ukrainy. - 2007. - 536 s.

Zaiets, 2014 - Zaiets N. M. Suchasna naochnist: perevahy y mozhlyvosti multymediinoi prezentatsii / Pedahohichna maisternia. - 2014. - № 12. S. 6-9.

Kyryliuk, 2011 - Kyryliuk S. M. Problemy vykladannia heohrafii u shkoli: Konspekt lektsii / ukl. Kyryliuk S. M. Chernivtsi: Chernivetskyi natsionalnyiuniversytet, 2011. -124 s. Dzherelo: https://collectedpapers.com.ua/category/problems_teaching_geography_schoos 
Kolmychkov, 2006 - Kolmychkov M. Bykorystannia elektronnykh atlasiv na urokakh heohrafii / M. Kolmychkov // Kraieznavstvo. Heohrafiia. Turyzm. - 2006. - №10-11. - S. 3-7.

Kushnarenko, 2014 - Kushnarenko Nataliia. Zastosuvannia inovatsiinykh tekhnolohii u navchanni fizychnoi heohrafii. / Nataliia Kushnarenko // Psykholoho-pedahohichni problemy silskoi shkoly. Vypusk 51. - 2014. - S. 52-58.

Markus, 2002 - Markus N. V. Osoblyvosti zastosuvannia informatsiinykh tekhnolohii yak zasobu humanizatsii navchannia shkoliariv / N. V. Markus // Onovlennia zmistu, form ta metodiv navchannia i vykhovannia v zakladakh osvity: 3b. nauk. pr. - Rivne. -2002 . - S. 171-173.

Nazarenko, 2008 - Nazarenko T. H. Zmist i struktura metodyky navchannia heohrafii v profilnii shkoli / T. H. Nazarenko // Heohrafiia ta osnovy ekonomiky v shkoli. - 2008. - № 7-8. - S. 18-20.

Novykov, 2003 - Novykov S. P. Prymenenye novыkh ynformatsyonnыkh tekhnolohyi v obrazovatelnom protsesse / S. P. Novykov // Pedahohyka. - 2003. - № 9. - S. 32-38.

Pekhota, 2004 - Pekhota O. M. Osvitni tekhnolohii / za red. O. M. Piekhoty. - K., 2004. - S. 44-46.

Pyrohov, 2011 - Pyrohov I. Multymediini zasoby u navchanni heohrafii / I. Pyrohov // Kraieznavstvo. Heohrafiia. Turyzm. - 2011. - № 38. - S. 7-8.

Pometun, 2004 - Pometun O. I. Suchasnyi urok. Interaktyvni tekhnolohii navchannia: naukovo-metodychnyi posibnyk / O. I. Pometun, L. V. Pyrozhenko. - K.: Vydavnytstvo A.S.K., 2004. - 192 s.

Інна Кононенко, кандидат педагогічних наук, старший викладач кафедри іноземної філології,

перекладу та методики навчання

ДВНЗ «Переяслав-Хмельницького державного педагогічного університету

імені Григорія Сковороди».

\section{Inna Kononenko,}

PhD in Pedagogy, Senior Lecturer

of the Department of Foreign Philology,

Translation and Teaching methods

State Higher Education «PereiaslavKhmelnytskyi Hryhorii Skovoroda State

Pedagogical University».

E-mail: innakononenko83@ukr.net

ORCID 0000-0001-9553-5339

\section{МУЛЬТИКУЛЬТУРАЛІЗМ ЯК ПЕРЕДУМОВА ПІДГОТОВКИ МАЙБУТНІХ УЧИТЕЛІВ ФІЛОЛОГІЧНИХ СПЕЦІАЛЬНОСТЕЙ У КОНТЕКСТІ ІНТЕГРАЦІЙНИХ ТА ГЛОБАЛІЗАЦІЙНИХ ПРОЦЕСІВ СВІТУ}

У статті розглянуто концепцію мультикультуралізму як передумову підготовки майбутніх учителів філологічних спеціальностей у контексті інтеграційних та глобалізаційних процесів у світі. Визначено концепції підготовки кваліфікованих майбутніх спечіалістів філологічних спеціальностей у площині мультикультуралізму. Виокремлено основні принципи основні напрямки професійного становлення майбутніх учителів філологічних спеціальностей у практиці вищої школи, щзо включають ознайомлення студентів з проблемами становлення та розвитку мультикультурних суспільств, різними аспектами спілкування $i$ стосунків між людьми в них. Охарактеризовано засоби підготовки студентів до міжкультурної комунікації в ході вивчення іноземних мов, формування у майбутніх учителів філологічних спеціальностей інтересу до професійної діяльності, підготовка студентів до використання педагогічних технологій в освітньому процесі для вирішення конкретних навчально-виховних завдань. Розглянуто сучасне реформування системи освіти Украӥни як один з компонентів євроінтеграційного процесу, де набуває актуальності питання використання міжпредметних зв'язків між викладанням іноземних мов $i$ міжкультурною комунікацією. Проаналізовано зв'язок між викладанням іноземних мов і міжкультурною комунікацією з позицій мультикультуралізму. Комунікативний аспект розглядається як основа взаємодії майбутніх фахівці філологічних спечіальностей, який передбачає реалізацію мети спілкування між різними соціокультурними групами. Застосування знань про іншомовний соціум забезпечують широкий спектр міжкультурного спілкування, формують готовність студентів до якісного міжкультурного ділового спілкування, до міжнародного професійного співробітництва. Навчання кваліфікованих фахівців філологічних спеціальностей у сфері мультикультуралізму спрямоване на засвоєння іноземної мови на внутрішньому рівні; застосовувати на практиці навички та знання іноземної мови; покрамення інтелектуального, загальнокультурного рівня майбутніх фахівців; для занять особистим розвитком; застосування етичних норм спілкування та їх застосування на практиці. 